University of New Hampshire

University of New Hampshire Scholars' Repository

Languages, Literatures, and Cultures

Scholarship

Languages, Literatures, and Cultures

5-1-1997

\title{
Using Portfolios to Develop L2 Cultural Knowledge and Awareness of Students in Intermediate Spanish
}

Lina Lee

University of New Hampshire, Durham, lina.lee@unh.edu

Follow this and additional works at: https://scholars.unh.edu/lang_facpub

Part of the Spanish and Portuguese Language and Literature Commons

Comments

Copyright (C) 1997 American Association of Teachers of Spanish and Portuguese. This article first appeared in Hispania 80:2 (1997), 355-367. Reprinted with permission by Johns Hopkins University Press.

\section{Recommended Citation}

Lee, Lina. Using portfolios to develop L2 cultural knowledge and awareness of students in Intermediate Spanish. Hispania, 80(2), 355-367, 1997. https://dx.doi.org/10.2307/345930

This Article is brought to you for free and open access by the Languages, Literatures, and Cultures at University of New Hampshire Scholars' Repository. It has been accepted for inclusion in Languages, Literatures, and Cultures Scholarship by an authorized administrator of University of New Hampshire Scholars' Repository. For more information, please contact Scholarly.Communication@unh.edu. 


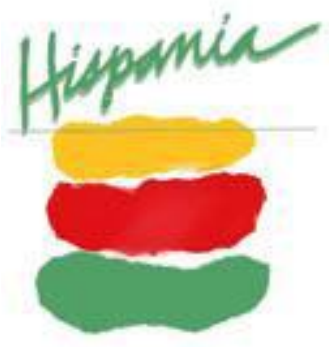

\section{Using Portfolios to Develop L2 Cultural Knowledge and Awareness of Students in} Intermediate Spanish

Author(s): Lina Lee

Source: Hispania, Vol. 80, No. 2 (May, 1997), pp. 355-367

Published by: American Association of Teachers of Spanish and Portuguese

Stable URL: http://www.jstor.org/stable/345930

Accessed: 30-05-2017 18:32 UTC

\section{REFERENCES}

Linked references are available on JSTOR for this article: http://www.jstor.org/stable/345930?seq=1\&cid=pdf-reference\#references_tab_contents You may need to $\log$ in to JSTOR to access the linked references.

JSTOR is a not-for-profit service that helps scholars, researchers, and students discover, use, and build upon a wide range of content in a trusted digital archive. We use information technology and tools to increase productivity and facilitate new forms of scholarship. For more information about JSTOR, please contact support@jstor.org.

Your use of the JSTOR archive indicates your acceptance of the Terms \& Conditions of Use, available at http://about.jstor.org/terms

American Association of Teachers of Spanish and Portuguese is collaborating with JSTOR to digitize, preserve and extend access to Hispania 


\title{
Pedagogy: Secondary, Colleges AND
}

UNIVERSITIES

\section{Using Portfolios to Develop L2 Cultural Knowledge and Awareness of Students in Intermediate Spanish}

\author{
Lina Lee \\ University of New Hampshire
}

\begin{abstract}
In spite of many efforts and contributions from previous researchers, the need for a systematic and consistent approach to teaching culture is still unmet. This pilot study shows that the portfolio is a meaningful way to integrate language and culture in a structure that provides opportunities for students to learn about foreign culture while using other skills-reading, listening, writing and speaking. In addition, resources from the Internet, such as Gopher, World Wide Web, and Listservs have great potential for cultural learning outside the classroom. Foreign language teachers should be encouraged to explore and experiment with portfolios in other content areas of language learning, since producing a portfolio involves higher-order cognition as well as all four communicative language skills.
\end{abstract}

Key Words: classroom-based research, cultural learning, portfolio instruction, authentic assessment, Internet resources, foreign language skills, cognitive skills, intermediate Spanish

\section{Introduction}

The increasing ethnic and linguistic diversity of our society, as well as its changing role in a growing global economy, make it necessary for foreign language learning and teaching to go beyond oral proficiency training. Foreign language educators need to re-think the objectives of foreign language education at all levels. Seelye (1994) points out that "learning a language in isolation of its cultural roots prevents one from becoming socialized into its contextual use" (10), while Crawford-Lange and Lange (1984) state that "to study language without studying the culture of native speakers is a lifeless endeavor" (140). If the ultimate goal of foreign language acquisition is genuine interaction with different cultures, then cultural competence is an essential component of language learning.

The shift in emphasis to the development of oral skills over the past decade has not been accompanied by an increasing awareness of the importance of consistently and persistently including a focus on the cultural components of language learning. It seems to be a matter of not having enough time to cover both linguistic and cultural information at the entry level of language classes. On the other hand, it is interesting to note that in the same time period we have really come to accept the critically important role that culture has to play in the language learning process. However, the question remains how to create a learning environment in which learners can gain both linguistic and cultural competence, preferably through exploration and personal experience.

\section{Brief Review of the Literature on L2 Culture Teaching}

For many years foreign language educators have expressed their concerns about students' lack of cross-cultural communicative competence. Omaggio Hadley (1993) points out that "American students' inadequate knowledge of the world is reflected not only in their lack of foreign language skills, but also in their general ignorance of basic information about other nations and peoples" (355). This "ignorance" of other cultures is found not only in students but in teachers as well. It is clear that a change in students' attitudes toward other cultures is urgently needed. Language teaching and 
learning can effect that change.

The essential issues of what, how, and when to teach and assess L2 culture have been discussed and debated among researchers since the 1960s (e.g., Brooks 1968; Lafayette 1976; Moore 1994; Nostrand 1974; Seelye 1994; Stern 1983; and Strasheim 1981, among others). In addition, several theoretical frameworks and models, along with strategies for teaching culture, have been proposed and developed (e.g., Breslin 1993; Galloway 1984, 1992; Meade and Morain 1973; Mydlarski 1979; Nostrand 1967; Seelye 1994; Lafayette 1978, 1988). For instance, Byrnes (1991) encouraged L2 learners to "reflect on their expectations visà-vis the L2 culture on the basis of their $\mathrm{C} 1$ frame of reference" (210) while constructing cultural activities. Seelye (1994) points out the importance of setting instructional goals, procedures, and measurement for teaching L2 culture (363-64).

Also ongoing among researchers is the debate between teaching culture with "little c" and culture with "big C" (e.g., Allen 1985; Brooks 1971; Lafayette 1976; Seelye 1984). The primary goal of teaching "little c culture" is to encompass people's traditions, customs, beliefs, behavior, and values, whereas teaching "big C culture" focuses on the study of the art, literature, music, history, and civilization of people through literary texts. The issue, perhaps, is no longer on "little c culture" versus "big C culture," but rather on the method of learning experientally rather than through memorization of facts. Teachers should avoid presenting L2 culture through a series of facts to be memorized. More importantly, the process of teaching L2 culture should focus on helping students understand and appreciate the target culture so that they feel comfortable to interact with native speakers.

In addition to the consideration of the idea of "little c culture" and "big C culture," there is the process of learning L2 culture that must be considered. Crawford-Lange and Lange (1984) believe that L2 culture should be learned as a process that cannot be separated from language acquisition it- self. They therefore propose an eight-stage model for the integration of language and cultural learning. They further point out that this integrative process "operates in both the cognitive and affective domains of general educational objectives" (155). The cognitive domain, as defined by Bloom et al. (1956), consists of six componentsknowledge, comprehension, application, analysis, synthesis, and evaluation. The affective domain involves attitudes; that is, the motivation to receive and respond to the situation. Both cognitive and affective domains facilitate the learning process and help learners gain the information in a meaningful way. The integrative language and culture model proposed by CrawfordLange and Lange (1984) is also a communicative approach which requires learners to use the target language "as a means of accomplishing perceptions, an understanding, and a valuing of the second culture" (162).

Since 1992 the Commission on Cultural Competence of the American Association of Teachers of French (AATF) has been working to establish a framework for determining standards of competence with respect to foreign cultures. The standards were published in the AATF National Bulletin (1995). They suggest that foreign languages should be taught in a broad way which allows learners to observe, analyze, and communicate efficiently in both verbal and non-verbal cultural contexts.

While there has been some attention to what and how to teach in terms of both language and culture, the measurement of foreign language assessment research has generally focused on receptive and productive skills, using either integrative or discrete-point formats. Not much attention has been paid to the assessment of cultural competence. Omaggio Hadley (1993), for example, dedicates an entire chapter to classroom testing of the four skills, but does not deal with culture. In the chapter on teaching for cultural understanding, however, she suggests that "in the absence of a welldefined assessment model for culture at the present time, activities might best be orga- 
nized in terms of instructional goal statements" (375).

Traditionally, L2 cultural knowledge has been measured by discrete-point formats, such as multiple-choice, true-false and fillin-the-blank. The research conducted by Moore (1994) shows that true-false and multiple-choice questions continue to be used most frequently. Objective tests, however, cannot measure "the ability to put together one's experience and knowledge" (Nostrand 1974). Often the objective tests lead to over-generalizations and stereotypical information (Seelye 1994). In general, anecdotes-fragments of information about the target culture-have been recounted rather than "insights or awareness of the essence of a culture or society" (Moore 1994). Moore urges language teachers to design "more creative and imaginative teaching, testing and assessing for culture, since the teaching and learning of culture cannot be done in bits and pieces" (168).

In spite of many efforts and contributions from previous researchers, the need for a systematic and consistent approach to teaching culture is still unmet. How can we bring theoretical models into classroom practice? How can we evaluate cultural knowledge and awareness? There are no widely agreed upon answers to these questions. Construction of a portfolio may be an appropriate way to develop in foreign language students knowledge, understanding, and awareness of L2 cultures. The discussion that follows describes and investigates the use of portfolios and their effects on foreign language learning.

\section{Overview of the Use of Portfolios}

Portfolios have been considered as an effective instruction and assessment tool for L2 teaching and learning. According to Resnick and Resnick (1992) and Valencia et al. (1990), portfolios are defined as any project that represents collections of artifacts of the student's learning experiences assembled over time. In general, three distinguishing characteristics of the portfolio are (1) student involvement, (2) evaluation and reflection of both the process and product of learning, and (3) work collected over time.

Portfolios can be used at all levels of instruction. The specific design and evaluation of portfolios depend on the actual purposes and objectives of learning and teaching. It has been recommended, however, that to best demonstrate the student's capabilities, portfolios should contain written and oral assignments, the student's selfevaluation, and documentation of the teacher's observation. Specific steps have been suggested for implementing portfolio use, including identifying the purpose of the portfolio, establishing the overall design and organization, selecting materials to be used, and choosing an evaluative strategy (Burke 1994).

The effectiveness of portfolios has been demonstrated in various subject areas, especially $\mathrm{L} 1$ and $\mathrm{L} 2$ reading and writing (e.g., Gentile 1992; O'Malley and Pierce 1992; and Valencia et al., 1990). The benefits to students are many. Portfolios may (1) support individual topics of interest, (2) train students to become independent and responsible for their own learning, (3) enhance learners' research and more complex higher thinking skills, (4) focus on the learning "process" rather than on the "product," and finally, (5) encourage students to reflect on their own learning progress. Portfolios are also beneficial from the pedagogical point of view. They are used to understand better the students' attitudes, knowledge, and achievement in the designated areas; to monitor the growth of students' knowledge of a determined content area; and to facilitate the teaching process and adjust instructional objectives. Individual meetings or interviews to discuss the portfolio help to improve the communication between teacher and student. Portfolios can serve not only as a pedagogical tool, but also as an authentic assessment measurement.

Authentic assessment strategies for foreign languages have been recognized by several states. One of the goals of New York State's Frameworks 2000 is that assessment include authentic, real world tasks, require 
higher order thinking skills, and provide multiple ways for students to demonstrate their knowledge, understanding, and skills in the foreign language (NYS Curriculum and Assessment Council 1993). In contrast, traditional norm-referenced tests fail to capture the authentic foreign language abilities needed in real-life situations. As a result, learners become passive recipients and targets of assessment rather than active participants in the learning process. The New York Education Task Force for Foreign Language Instruction has considered the use of portfolio assessment in areas of foreign language learning (NYSAFLT 1993). The portfolio assessment allows both teachers and students to communicate, understand and reflect better on their own teaching and learning process and progress. The discussion that follows describes the use of portfolios for developing L2 cultural knowledge and awareness.

\section{Use of Portfolios for the Development of L2 Cultural Knowledge and Aware- ness}

It is natural to feel that we do not have sufficient time to cover a variety of cultural aspects at the entry level of language classes. Foreign language teachers have long faced problems in choosing which aspects of culture to teach and how to measure what students have learned, and especially how to bridge the gap between learners' linguistic and cultural competence. The use of portfolios can be the solution to these dual problems of content selection and assessment.

Portfolios provide students with a practical and meaningful way to gain both language and cultural knowledge, and offer many advantages to students. First, they evoke learners' interest by allowing students to focus on cultural components that interest students most. Second, the portfolio method leads them to investigate a foreign culture individually and in greater depth than they would be able to do in a normal teacher-centered classroom context. Third, selecting, planning, organizing, and producing a portfolio involves higherorder cognition as well as the four basic language skills (Moore 1994). Thus, portfolios can serve several purposes simultaneously.

For instance, students may choose specific topics of their interest such as "Latinos en los EEUU," "La cocina mexicana," "Pablo Neruda," "Los Incas en Perú," or "Mujeres en el mundo latino." For the topic "Pablo Neruda" the student focuses on several aspects such as "La juventud/vida de Pablo Neruda," "Sus poemas y su estilo de escribir," or "Pablo Neruda y su país: Chile." The student then searches for the information, reads and organizes the materials, and writes essays for each chosen aspect. The student shares the information about the topic with the class through oral presentations. Students ask questions, share their opinions, and make comments about the topic during oral presentations. Finally, the student compiles and self-evaluates the portfolio through the questionnaire provided by the instructor.

In brief, compiling a portfolio is learnercentered. The student is free to choose the topic. The student employs higher-order cognition as well as a combination of other language skills.

Several things need to be kept in mind when using portfolios in the intermediate language class. First, students' prior cultural knowledge needs to be measured in order to identify their strengths and weaknesses. Second, portfolios should be used as a required part of the course. Third, the definition, purpose, content, procedure, and assessment criteria for the portfolio need to be carefully presented to students. When possible, samples of portfolios with different designs and topics should be available as models. Finally, the portfolio process needs to be reexamined periodically by the instructor.

The following section suggests ways in which portfolios can be implemented to develop and assess Hispanic cultural knowledge and awareness while improving communication skills in a classroom setting. 


\section{The Pilot Study}

A pilot study using portfolios to develop students' Hispanic cultural knowledge and understanding provides several valuable insights into the process of acquiring a foreign language culture. The pilot study was conducted during a nine-month period. The sample group comprised all 52 students in Intermediate Spanish, both third-semester (Spanish 213) and fourth-semester (Spanish 214) courses at a small public institution in a rural area of the Northeast. Students were familiar with the basic vocabulary and grammatical structures of Spanish, but had limited knowledge of Hispanic culture.

Written Spanish Proficiency Test. A Spanish Written Proficiency Test designed by the researcher was given to all participants prior to the study. The test's purpose was to ascertain the students' cultural competence and compare it to their language skills. The test was developed based on a set of instructional objectives. These objectives and their corresponding test items reflected three categories: comprehension, understanding, and application. The evaluation of the content of the items was based on a fourpoint scale. The rating ranged from "not adequate" to "very adequate." Three Spanish instructors reviewed the items for content validity. Reliability was verified through the test-retest procedure before conducting the study. The test-retest reliability alpha coefficient with a three-week interval $(\mathrm{N}=26)$ was .86 . The coefficient was significant at .001 level. The following list provides sections, the format, and the number of questions for each section:

(I) Listening: 2 passages in Spanish (4 true/false; 4 short questions)

(II) Grammar: 20 sentences in Spanish (multiple-choice)

(III) Reading: 1 short and 1 long passage in Spanish (4 multiple-choice; 4 short questions)

(IV) Writing: 1 short essay (120 words for a situation)

(V) Culture:

The Hispanic cultural items consist of three parts: (1) questions in English, (2) questions in Spanish, (3) short questions in Spanish. Samples for each of the three parts include the following:

(1) Questions in English:

- Which of the following expressions would normally be used to welcome someone to your house?

(a) ¡Oye! (b) Mi casa es su casa. (c) ¿Qué tal? (d) ¡Mucho gusto!

- In the Hispanic world, the major meal of the day is

(a) el desayuno (b) el almuerzo (c) la cena

(d) la merienda

(2) Questions in Spanish:

- Juana Ramos se casó el sábado pasado con el hijo menor de la Sra. María Rosales Pérez, el cual se llama José Rosales Baca. Ahora Juana firma los documentos legales como
(a) Juana Ramos
(b) Juana Pérez
(c) Juana

Baca (d) Juana Rosales

- Es común que los abuelos hispanos vivan (a) en casas para ancianos (b) en apartamentos privados (c) con sus hermanos (d) con sus hijos

(3) Short questions in Spanish:

- Explique Ud. brevemente la celebración del Día de los Muertos en México.

- Mencione Ud. cinco países de Latinoamérica y sus capitales respectivas.

The results of the test-which considers culture only in the form of factual knowledge-showed that students' cultural competence was lower than that of all their other skills (see Table I and II). Table I shows that there was no major difference in culture scores between SPA 213 and SPA 214. This indicates that most of the students had very little exposure to Hispanic culture before this study. Table II indicates that the students of SPA 214 scored higher in cultural knowledge than those who were in SPA 213. Some of the students who were enrolled in SPA213 in the Fall 1994 continued with SPA 214 in the Spring 1995. When they were retested at the beginning of the spring semester, their cultural knowledge increased from $36.9 \%$ to $50.4 \%$. This increase may be 
attributed to the portfolio construction during the fall semester. In addition, having carried out tasks that exposed them to Hispanic culture through a variety of resources, such as Spanish TV, newspapers and textbooks, those who took SPA 213 in the Fall 1994 and continued with SPA 214 in the Spring 1995 might be more aware of the importance of Hispanic culture. Therefore, they had gained some basic Hispanic cultural knowledge which they were able to demonstrate on the test.

Interestingly, the results showed a drop in grammar and writing scores on the test in SPA 214 in Spring 1995. An unfamiliarity with the content areas of the test and less motivation to foreign language learning might be possible factors in the results. A more plausible explanation might be that the overall language proficiency of some of the students from the Spring 1995 course was inferior to that of those enrolled in the Fall 1994 course.

Design and Procedures. The results of the Spanish written proficiency test demonstrated the need for incorporating a cultural cerning the use of portfolios was provided to all the students in both of the Intermediate Spanish courses. Students were introduced to Galloway's four-stage approachthinking, looking, learning, and integrating information (1992). This approach was expected to improve students' reading skills as well as their knowledge about the understanding of Hispanic culture.

A brief introduction to portfolios was made to all students. They were given a written statement of objectives, procedures, and assessment criteria (Appendix A) as well as a list of suggested topics for their portfolios. Students chose their own topics of interest concerning the Hispanic world. It was assumed that certain topics and countries were repeatedly chosen over others due to self-selection. However, different aspects of these topics were presented through students' writing.

Interestingly, Mexico, Spain, the Dominican Republic, Chile, Argentina, and Cuba, were the countries most often chosen. This may be because of the presence on campus of Southern Cone Programs, students from

Table I (Fall 1994)

Spanish Written Proficiency Test

\begin{tabular}{|c|c|c|c|c|c|}
\hline Class & Listening & Grammar & Reading & Writing & Culture \\
\hline SPA 213 & $44 \%$ & $47 \%$ & $55 \%$ & $60 \%$ & $36.9 \%$ \\
\hline SPA 214 & $54 \%$ & $50 \%$ & $70 \%$ & $78 \%$ & $39 \%$ \\
\hline
\end{tabular}

Table II (Spring 1995)

Spanish Written Proficiency Test

\begin{tabular}{|c|c|c|c|c|c|}
\hline Class & Listening & Grammar & Reading & Writing & Culture \\
\hline SPA 213 & $52 \%$ & $42.6 \%$ & $56.5 \%$ & $57 \%$ & $36.4 \%$ \\
\hline SPA 214 & $57 \%$ & $48.1 \%$ & $65.4 \%$ & $73.3 \%$ & $50.4 \%$ \\
\hline
\end{tabular}

component into the foreign language syllabus design for the intermediate Spanish classes. The portfolio was used to develop Hispanic cultural knowledge as part of the course requirements. The major goal of this particular portfolio was to increase understanding and knowledge of Hispanic culture as well as to tie cultural learning into the development of language skills. At the beginning of the semester, information con- the Dominican Republic and Argentina, as well as professors associated with Spain or Mexico. Food, holidays, art, music, gender roles, housing, immigration, and sports were frequently chosen topics. This may be because students are already familiar with them through their textbooks and find there the necessary vocabulary and factual information. The following list shows samples of most often selected countries 
with sample titles of topics that students chose to write about:

\section{México:}

a) Días festivos-Quinceañera, El día de los muertos, El día de la Virgen de Guadalupe b) Cocina/comida-Costumbres de comer, Los mercados, Platos típicos

c) Inmigración-Sistema político, Problemas económicos, Los inmigrantes en los EE.UU.

\section{España:}

a) Ciudades-Madrid, Barcelona, Sevilla

b) Monarcas-Carlos I, Felipe II, Felipe V

c) Pintores-Miró, Goya, Picasso, Juan Gris

d) Vida social-Hombre y mujer, Amor y matrimonio, Boda

e) Festividades-La corrida de toros, Pamplona, Semana Santa

\section{Argentina:}

a) Gente y ambiente-Jorge Luis Borges, Buenos Aires, Gauchos y pampas

\section{Chile:}

a) Pablo Neruda-La juventud/vida de Pablo Neruda, Sus poemas y su estilo de escribir, Pablo Neruda y su país, Chile

b) Educación/profesión-El sistema educativo, Las universidades principales, Tipos de empleo

5. Cuba:

a) Béisbol-La gente y el béisbel, José Canseco, Livan Hernández

b) Música-Celia Cruz, Gloria Estefan, Jon Secada

During the semester, the instructor met with students to establish goals, select materials, compose tasks, and help them selfevaluate their portfolios in progress. It has been argued that formal and final observations should not be placed in the portfolio until they have been discussed with the student (Wilson 1994). In this way students could identify both areas of progress and areas in need of improvement. A copy of a checklist, along with a self-evaluation scheme, was provided for students to be included in the final portfolio (Appendix B).

Resources from the Internet, such as Mosaic, World Wide Web sites, and
Listservs have great potential for cultural learning outside the classroom. The online, current information from countries around the world allows students to explore and examine various sources as well as to read authentic materials. Daily news concerning the Hispanic world on cable TV, audio and video tapes, newspapers, and magazines are valuable cultural resources. Students were advised to use these resources to examine specific cultural aspects. Students were also asked to select, read, and react to the authentic materials they chose to support their writing assignments. The following list summarizes the major activities involved in the portfolio and language skills required to carry out the tasks:

1. Write three two-page compositions with a minimum of three supporting materials for each composition (reading and writing skills).

2. Re-write the compositions after receiving feedback from the instructor (writing skills).

3. Make two ten-minute oral presentations with five-minute discussion among students (listening and speaking skills).

4. Attend the weekly conversation workshop and write journal entries for the presentations or/and video clips (listening, speaking, writing, and thinking skills).

5. Meet with the instructor for the final oral interview (cultural knowledge/awareness and language skills).

During the semester, students were required to write three compositions about selected cultural topics based on their readings of supporting authentic materials. After receiving feedback from the instructor, they were expected to revise their compositions. Students made oral reports on the cultural aspects discussed in their compositions, so that oral skills could be reinforced and improved. The written scripts of these oral presentations were corrected beforehand by the instructor so that students would not memorize grammatically incorrect phrases. Each student in the class had to contribute a minimum of six ques- 
tions or comments after each presentation in order to ensure discussion, exchange of ideas, and learning.

In addition to the writing assignments and oral presentations, students made weekly journal entries about the videotapes and presentations given by non-foreign language faculty as regular components of the conversation workshop. Invited faculty from other departments attended the conversation workshop to speak on various topics related to Hispanic culture. Journal entries were part of portfolio assignments and were collected once a month. The instructor read the entries, providing feedback to students or/and answering their questions. Grades for journal entries were not assigned until the end of semester.

The final oral interview is an important tool for assessing the cultural learning through portfolio use. In addition to writing a self-evaluation, students had to answer a number of questions during the final oral interview. These were designed to gather more detailed information about the progressive accumulation of knowledge about a culture, as well as to learn whether students actually gained cultural knowledge and awareness (Appendix C).

The final interview provided the instructor with an important opportunity to observe what experiences of Hispanic culture that students had gained by means of the portfolio. Objective tests, it has been noted, often fail to measure precisely this ability to "put together one's experience and knowledge" (Nostrand 1974). The use of authentic materials, improvement of cultural knowledge, as well as reading, writing, and speaking skills; change of attitude toward the target culture; the increase (decrease) of motivation to learn about culture as part of language acquisition-all examined repeatedly during the semester-could receive final assessment during this exit interview.

In sum, the final portfolio contained: (1) three compositions in both draft and revised forms, (2) the written scripts of two oral presentations, (3) journal entries for the conversation workshop, (4) supporting materials for the project, such as photocopies of readings with bibliography, audio and video tapes, (5) a final written report, and (6) a final oral interview. Each component was graded separately based on five categories: content, organization, language, style, and appropriateness (Part III of Appendix A contains details). The global grading criteria was used for each item. For instance, the final written report (20\%) was evaluated based on the scale: Very good $=20$, Good=15, Fair=10, Poor $=5$.

\section{Results and Discussion}

The results of this study were based on the self-evaluation questionnaire and the final interview. Overall, students reacted positively to portfolios. Table III reports the results of the self-evaluation questionnaires from students. They were asked to respond to the following statements by ranking the level of satisfaction with the number from 1-5.

1. The portfolios helped me improve my writing skills.

2. The oral presentations for the portfolio helped me improve my speaking skills and express my ideas better.

3 . The use of the portfolio as part of the course helped me learn Spanish in a meaningful way.

4. The process of developing my portfolio increased my knowledge of Hispanic culture.

5. I made an effort to prepare my portfolio. 6. My portfolio is comprehensible and interesting.

The results indicate that most students agreed that portfolios are an effective way to develop Hispanic cultural knowledge, and improve writing and speaking skills. Virtually all students, $97.4 \%$, agreed that the required portfolio helped them gain a practical knowledge of Spanish. Students also reported that they had made an effort to carry out the project and believed that the portfolio was interesting and comprehensible to them. A brief outline of the most salient results appears below. 
Table III

Total \# of students: 39

$\begin{array}{lll}\text { Question } & \begin{array}{l}\text { Strongly } \\ \text { Agree }\end{array} & \text { Agree } \\ \# 1 & 12(30.8 \%) & 26(66.7 \%) \\ \# 2 & 7(18 \%) & 21(53.8 \%) \\ \# 3 & 17(43.6 \%) & 19(48.7 \%) \\ \# 4 & 16(41 \%) & 15(38.5 \%) \\ \# 5 & 14(35.9 \%) & 18(46.1 \%) \\ \# 6 & 16(41 \%) & 17(43.6 \%)\end{array}$

Results of Self-evaluation Questionnaire

Multiple learning skills improved. Most of all, this type of portfolio proved to be an effective means of assessing multiple learning skills (Moore 1994). Not only did students' cultural knowledge and language skills improve, but also their cognitive abilities because they had to select, organize, analyze, and summarize information during the process of compiling the portfolio. This particular portfolio design also allowed students to investigate specific aspects of Hispanic culture and to share information with their peers. Students felt that writing and revision of the scripts of their culture presentations helped them understand the target culture and language, and prepare for their oral presentations and final reports.

Students agreed that the opportunities to listen to similar topics from different presentations helped them understand better specific aspects of Hispanic culture, reinforced their listening skills and increased their knowledge of vocabulary. In addition, some students indicated that their listening comprehension and skills were improved through audio/video tapes and oral presentations, although they had difficulties in understanding some of the materials and presentations. Finally, writing weekly journals helped them reinforce their thinking and writing skills while processing the Hispanic cultural information acquired from the presentations.

Learning styles highlighted. A total of $7.7 \%$ of students claimed that they did not benefit from the use of portfolios. Students' individual learning styles, personalities, and motivation might help explain their reac-

$\begin{array}{lll}\begin{array}{l}\text { Agree } \\ \text { Somewhat }\end{array} & \text { Disagree } & \begin{array}{l}\text { Strongly } \\ \text { Disagree }\end{array} \\ 1(2.5 \%) & 0(0 \%) & 0(0 \%) \\ 11(28.2 \%) & 0(0 \%) & 0(0 \%) \\ 2(5.1 \%) & 0(0 \%) & 1(2.6 \%) \\ 5(12.8 \%) & 3(7.7 \%) & 0(0 \%) \\ 7(18 \%) & 0(0 \%) & 0(0 \%) \\ 6(15.4 \%) & 0(0 \%) & 0(0 \%)\end{array}$

tions to the portfolio. For instance, some students pointed out their frustration at not being able to find sufficient information for the project and their anxiety when speaking in front of the class. A few students indicated that they were only interested in practicing and speaking more Spanish in class rather than learning Hispanic culture. Therefore, they were not motivated to gain knowledge of Hispanic culture. One of the main reasons for many students to learn a foreign language is to be able to communicate with others (Horwitz and Young 1991; Oxford 1990b). The priority placed on improving communicative skills might explain the students' low interest in gaining knowledge of Hispanic culture.

Attitude and motivation changed. The construction of portfolios had a very positive effect on learning both Hispanic culture and Spanish language. As a result, students became more motivated and positive about language learning. During the final oral interview, some students expressed interest in traveling to Hispanic countries or joining the Spanish Club on campus so that they could communicate with native speakers and learn more about Hispanic culture. Students seem to have realized that learning culture as part of language acquisition can be more enjoyable than anticipated, although some of them found writing and speaking assignments difficult and challenging. Some students commented that while they did not see the significance of learning about culture at the beginning of the course, they had changed their minds and had begun to perceive the importance 
of being able to relate what they had learned about foreign cultures to their own culture. This seems to confirm the importance of attitude change and motivation for cultural learning (Seelye 1991). In addition, students felt that they had been actually engaged in the learning process and were not just passive recipients of facts presented by the teacher.

Technological knowledge and skills gained. In addition, the technological resources from the Internet and other available resources on campus helped students examine specific cultural aspects closely. They found valuable Hispanic cultural resources on the Internet and learned how to use several computer tools (Netscape, Gopher, and Listserv) for the project. Students stated that they enjoyed searching for the cultural information through the Internet, and they gained research and technological skills, although they needed guidance and assistance at first. Some students suggested that both teachers and students needed to receive the appropriate training on how to access and apply the information from the Internet effectively. This study also confirmed Schneider's (1982) finding that substantial technical and pedagogical instruction is needed to achieve best use of the new technology.

\section{Summary and Conclusions}

Based on the data collected and available at this time, a number of conclusions can be drawn. Teaching L2 culture should be included in the curricular plan. The compiling of a portfolio is an effective means for developing and assessing knowledge of the target culture. Because of the large size of many language classes and the consequently limited time for cultural activities, teachers need a method for teaching culture that is efficient. Portfolios are a way to integrate language and culture in the classroom setting in a structure that provides opportunities for students to learn about foreign culture while using other skills-reading, listening, writing, and speaking. Portfolios encourage students to use authentic materials to investigate specific cultural aspects that interest them. The portfolio encourages students to reflect upon what they are learning in journals. While learning, they use higher-order cognitive skills. The portfolio also helps them become independent and "responsible for their own learning" (Moore 1994).

This study provides a rationale for using portfolios for cultural learning with one example given to show how to organize a portfolio assignment. This study suggests the need for further research to find out how portfolios can be designed and developed for cultural learning in advanced courses. In addition, this study encourages teachers to assign students cultural topics in order to ensure the varied selection of aspects of Hispanic culture. Furthermore, it would be useful for foreign language teachers to have an exchange of ideas about portfolios so that more standardized procedures for teaching and assessing L2 culture could be elaborated.

Given the positive effects of portfolios on cultural learning as shown in this study, foreign language teachers should be encouraged to explore and experiment with portfolios in various content areas of language learning. Producing a portfolio involves higher-order cognition as well as all four basic language skills, thus making it possible to integrate language and culture in the classroom setting. Foreign language teachers, by means of the portfolio, have a more efficient way to encourage and assess the knowledge their students have gained of the target culture.

\section{Works Cited}

Allen, Wendy W. "Toward Cultural Proficiency." Proficiency, Articulation, Curriculum: The Ties that Bind. Ed. A. Omaggio. Reports of the Northeast Conference on the Teaching of Foreign Languages. Middlebury, VT: Northeast Conference, 1985. 137-65.

“AATF Framework for Cultural Competence." AATF National Bulletin, Jan. 1995.

Bloom, B. S., et al. Taxonomy of Educational Objectives, Handbook I: The Cognitive Domain. New York: David McKay, 1956. 
Breslin, R. Understanding Culture's Influence on Behavior. New York: Harcourt, Brace and Jovanovich, 1993.

Brooks, Nelson. "Teaching Culture in the Foreign Language Classroom." Foreign Language Annals 1 (1968): 204-17.

-. "A Guest Editorial: Culture-A New Frontier." Foreign Language Annals 5 (1971): 54-61.

"Building a Learning-Centered Curriculum for Learner-Centered Schools." New York State Curriculum and Assessment Council Interim Report to the Commission of Regents. Nov. 1993.

Burke, Kay. The Mindful School: How to Assess Authentic Learning. Palatine, Illinois: IRI/Skylight, 1994.

Byrnes, Heidi. "Reflections on the Development of Cross-Cultural Communicative Competence in the Foreign Language Classroom." Foreign Language Acquisition Research and the Classroom. Ed. B. Freed. Lexington, MA: D. C. Heath, 1991. 205-18.

Crawford-Lange, Linda, and Dale Lange. "Doing the Unthinkable in the Second Language Classroom." Teaching for Proficiency, the Organizing Principle. ACTFL Foreign Language Education Series, Vol. 15. Ed. T. Higgs. Lincolnwood, IL: National Textbook Company, 1984. 139-77.

Galloway, Vicki B. "Communication in a Cultural Context.” ACTFL Master Lecture Series. Monterey, CA: Defense Language Institute, 1984.

—. "Toward a Cultural Reading of Authentic Texts." Languages for a Multicultural World in Transition. Reports of the Northeast Conference on the Teaching of Foreign Languages. Ed. H. Byrnes. Lincolnwood, IL: National Textbook Company, 1992. 87-121.

Gentile, C. "Exploring New Methods for Collecting School-based Writing: UNAEP's 1990 Portfolio Study." National Assessment of Educational Progress. Princeton, New Jersey, 1992.

Horwitz, Elaine K., and Dolly J. Young. Language Anxiety: From Theory and Research to Classroom Implications. New Jersey: Prentice-Hall, 1991.

Lafayette, Robert, ed. The Culture Revolution in Foreign Language Teaching. Lincolnwood, IL: National Textbook Company, 1976.

- Teaching Culture: Strategies and Techniques. Language in Education: Theory and Practice, 11. Washington, DC: Center for Applied Linguistics, 1978.

-. "Integrating the Teaching of Culture into the Foreign Language Classroom." Toward a New Integration of Language and Culture. Reports of the Northeast Conference on the Teaching Foreign Languages. Ed. A. J. Singerman. Middlebury, VT: Northeast Conference, 1988. 47-62.

Meade, B., and Morain, G. "The Culture Cluster." The Modern Language Journal 6 (1973): 331-38.

Moore, Zena. "The Portfolio and Testing Culture." Teaching, Testing, and Assessment. Reports of the
Northeast Conference on the Teaching Foreign Languages. Ed. C. Hancock. Middlebury, VT: Northeast Conference, 1994. 161-82.

Mydlarski, D. "Using the Micrologue in the Language Classroom." Canadian Modern Language Review 35 (1979): 625-68.

"New York State Association of Foreign Language Teachers." NYSAFLT Bulletin, Fall 1993.

Nostrand, Howard L. Background Data for the Teaching of French. Part A: La culture at la société françaises au XXe siècle. Seattle: U of Washington, 1967.

—. "Empathy for a Second Culture: Motivations and Techniques." Responding to New Realities. ACTFL Foreign Language Education Series, Vol. 5. Ed. G. A. Jarvis. Lincolnwood, IL: National Textbook Company, 1974. 263-327.

Omaggio Hadley, Alice. Teaching Language in Context. Boston: Heinle \& Heinle, 1993.

O'Malley, J. Michael, and Pierce, L. "Performance and Portfolio Assessment for Language Minority Students." Washington, DC: National Clearinghouse for Bilingual Education, 1992 (ERIC Document $346747)$.

Oxford, Rebecca. Language Learning Strategies: What Every Teacher Should Know. New York: Newbury House/Harper \& Row., 1990b.

Resnick, L. B., and Resnick, D. L. "Assessing the Thinking Curriculum: New Tools for Educational Reform." Future Assessments: Changing Views of Aptitude, Achievement, and Instruction. Eds. B. R. Gifford and M. C. O'Connor. Boston, MA: Kluwer, 1992. 37-75.

Schneider, E. W. "Considerations on the Use of Technology in the Learning of Foreign Languages." Monterey, CA: Foreign Language Instructional Technology Conference (ERIC Document ED 236 910).

Seelye, H. Ned. Teaching Culture: Strategies for Intercultural Communication. Lincolnwood, IL: National Textbook Company, 1984, 1991, 1994.

Stern, H. H. "Toward a Multidimensional Foreign Language Curriculum.” Foreign Languages: Key Links in the Chain of Learning. Report of the Northeast Conference on the Teaching of Foreign Languages. Ed. R. Mead. Middlebury, VT: Northeast Conference, 1983. 35-47

Strasheim, Lorraine. "Establishing a Professional Agenda for Integrating Culture into K-12 Foreign Languages: An Editorial." The Modern Language Journal 65 (1981): 67-69.

Valencia, S., et al. "Assessing Reading and Writing: Building a More Complete Picture for Middle School Assessment." Technical Report. Urbana, Illinois: Center for the Study of Reading, 1990.

Wilson, Jo Anne. Using Portfolios in the Foreign Language Classroom. Austin, Texas: Holt, Rinehart, Winston, 1994. 


\section{Appendix A}

Guideline for the Portfolio

\section{Objectives:}

Increasing your knowledge of Hispanic culture is an extremely important part of your language learning process. Therefore, the purpose of the portfolio is to provide you with the opportunity to conduct a small research project related to cultural aspects of Spain, Mexico, or another Latin American country. You should select one area of interest (see the handout for possible topics) and start collecting material. You may use some of the information for this project to compose your writing assignments and oral presentations for this course. In addition to the project, you are required to make weekly journal entries for the discussions for the conversation workshop on Thursdays. These journal entries are to express your comments on readings and class discussions. All entries should be dated and written in a blue book (the examination booklet).

\section{Procedures:}

1. Select the topic that interests you most.

2. List the components you want to put in your portfolio.

3 . See your instructor for advice or suggestions.

4. Start searching for sources, such as magazines, newspapers, internet, videotapes, TV, books, inter-library loans, publications from the Mexican or Spanish embassies.

5 . Write a report (4-5 pages) and your journal entries in Spanish.

6 . Share your project with your instructor at the end of the semester.

\section{Criteria for the evaluation:}

Your portfolio will be evaluated based on the following:

1. Journal entries $20 \%$

2. Revised compositions/Script for oral presentations

3. Supporting materials
4. Written report $20 \%$

5. Oral interview $20 \%$

Each item will be graded based on its content, organization, language, style, and appropriateness.

Each item will be evaluated based on the following scale:

Very good $=20$, Good=15, Fair $=10$, Poor $=5$

\section{Appendix B}

Evaluation for the Portfolio

I. General information:

1. Title of portfolio:

2. Objectives:

3. Outlines:

4. Materials included:

5. Supporting sources:

II. Self-evaluation: $\mathrm{SA}=$ strongly agree (5), $A=$ agree (4), AS=agree somewhat (3), $\mathrm{D}=$ disagree $(2), \mathrm{SD}=$ strongly disagree $(1)$

1. The portfolio helped me improve my writing skills.

2. The oral presentations for the portfolio helped me improve my speaking skills and express my ideas better.

3. The use of the portfolio as part of the course helped me learn Spanish in a meaningful way.

4. The process of developing my portfolio increased my knowledge of Hispanic culture.

5. I made an effort to prepare my portfolio.

6. My portfolio is comprehensible and interesting.

7. Any concerns and comments:

\section{Appendix C}

Final Oral Interview Questions for the Portfolio

1. Briefly explain your project to me. 
- Topic:

- Objective(s):

- Content:

2. Tell me what authentic materials you used to support your project, and where and how you found the materials.

- Sources:

- Where:

3. Explain to me what was most valuable or interesting about this project for you and why?

- Valuable thing:

- Because:

4. Describe to me the most difficult or least important part of this project and explain.

- Difficulty:
- Because:

5. Share with me some of the cultural information in your portfolio.

- Observed phenomena:

- Learned knowledge:

- Cross-cultural understanding:

- Attitude changed:

6. Tell me if this project met your original goals for culture learning and why.

- Goals met:

- Goals not met:

7. Overall, describe to me how the experience of this project improved your other language skills.

- Skill(s) improved:

- Skill(s) not improved: 